\title{
ANATOMY VISUAL LEARNING: A NEW MODALITY TO ENHANCE NEUROANATOMY LEARNING IN FIRST-YEAR MEDICAL STUDENTS
}

\author{
Sasanthy Kusumaningtyas ${ }^{1,2^{*}}$, Mochamad Iskandarsyah Agung Ramadhan ${ }^{1}$, Ria Margiana ${ }^{1}$, \\ Elvan Wiyarta ${ }^{1}$, Reynardi Sutanto ${ }^{1}$, Isabella Kurnia Liem ${ }^{1,2}$ \\ ${ }^{1}$ Fakultas Kedokteran Universitas Indonesia, Jakarta - INDONESIA \\ ${ }^{2}$ Indonesia Museum of Health and Medicine (IMuseum) IMERI FKUI, Jakarta - INDONESIA
}

Submitted: 08 Jan 2020; Final Revision from Author: 20 Oct 2020; Accepted: 29 Dec 2020

\begin{abstract}
Background: In gaining knowledge and comprehension of neuroanatomy, medical students require not only memorizing the anatomical structures but also understanding the spatial relationships. Along with the cadaver prosection usage, we proposed an anatomy visualization learning (AVL) as possible modality to fulfill this need, yet this has to be proven. This study aimed to know whether AVL can improve student knowledge in neuroanatomy and give a positive perception to the student.

Methods: A quantitative and qualitative studies were performed to the first-year medical students $(n=46)$ of Faculty of Medicine Universitas Indonesia who were randomly divided into two groups, an interventional $(n=23)$ and a control ( $n=23$ ) group. Both groups enrolled in the neuroanatomy learning module, with additional two sessions (two hours/session) of AVL using 3D anatomy visualization table for the intervention group. Quantitative study to know the knowledge improvement was done by comparing the pre-test, post-test and gain scores between groups. Student's perception of the learning method was done using a questionnaire on a Likert scale. Qualitative study was done using open questions.

Results: The median value of the pre-test score (8 [0-30] vs. 4 [0-42]; $p=0.869)$ and the post-test scores (44 [30-82] vs. 40 [8-84]; $p=0.068$ ) between the interventional ws control group were not different. Nevertheless, the interventional

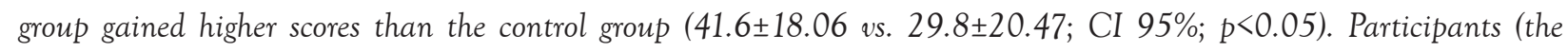
interventional group) had a positive perception about the AVL usage for neuroanatomy learning.
\end{abstract}

Conclusion: AVL can be considered as a new approach modality for neuroanatomy learning.

Keywords: anatomy visualization learning, $A V L$, neuroanatomy learning, anatomy learning

\begin{abstract}
ABSTRAK
Latar belakang: Dalam memperoleh pengetahuan dan pemahaman tentang neuroanatomi, mahasiswa kedokteran dituntut tidak hanya menghafal struktur anatomi tetapi juga memahami hubungan spasialnya. Sejalan dengan penggunaan proseksi kadaver, kami mengusulkan penggunaan pembelajaran visualisasi anatomi (anatomy visualization learning/AVL) sebagai perangkat pendukung untuk memenuhi kebutuhan tersebut. Penelitian ini bertujuan untuk mengetahui apakah AVL dapat meningkatkan pengetahuan neuroanatomi mahasiswa dan memberikan persepsi positif bagi mahasiswa.
\end{abstract}

*corresponding author, contact: ythnasas@gmail.com 
Metode: Studi kuantitatif dan kualitatif dilakukan pada mahasiswa Fakultas Kedokteran Universitas Indonesia tahun pertama $(\mathrm{n}=46)$, yang secara random dibagi menjadi dua kelompok, yaitu kelompok intervensi $(n=23)$ dan kontrol $(n=23)$. Kedua kelompok mengikuti pembelajaran modul neuroanatomi, dengan dua sesi pembelajaran tambahan menggunakan AVL (2 jam/sesi) untuk kelompok intervensi. Studi kuantitatif dilakukan dengan membandingkan skor pre-test, post-test dan peningkatan skor kedua kelompok. Persepsi mahasiswa mahasiswa dilakukan dengan kuesioner menggunakan skala Likert. Studi kualitatif dilakukan dengan pertanyaan terbuka.

Hasil: Tidak ada perbedaan nilai median skor pre-test (8 [0-30] vs. 4 [0-42]; $p=0,869)$ dan post-test (44 [30-82] vs. 40 [8-84]; $p=0,068$ ) antara kelompok intervensi dan kontrol. Namun, kelompok intervensi menunjukkan

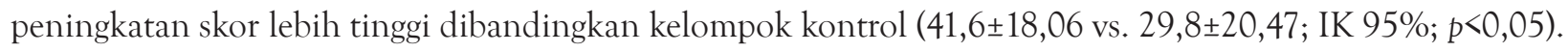
Peserta (kelompok intervensi) mempunyai persepsi positif terhadap penggunaan AVL untuk pembelajaran neuroanatomi.

Kesimpulan: AVL dapat digunakan sebagai perangkat baru dalam pembelajaran neuroanatomi.

Kata kunci: Anatomy visualization learning, AVL, pembelajaran neuroanatomi, pembelajaran anatomi

\section{PRACTICE POINTS}

- Penggunaan AVL memungkinkan mahasiswa mempelajari struktur detil neuroanatomi yang sulit terlihat pada pembelajaran dengan kadaver atau atlas dua dimensi.

- Pembelajaran dengan AVL dapat dilakukan bersama dengan penggunaan kadaver.

- Pembelajaran dengan AVL akan lebih baik dilakukan dalam kelompok kecil.

\section{PENDAHULUAN}

Anatomi merupakan salah satu cabang ilmu kedokteran yang penting dan mendasar, tidak hanya untuk memahami susunan dan fungsi normal tubuh manusia, tetapi juga dalam aplikasi klinisnya, baik dalam memahami perjalanan suatu penyakit, maupun penelusuran diagnosis suatu penyakit., ${ }^{1,2}$ Dalam mempelajari anatomi, mahasiswa kedokteran tidak hanya dituntut untuk menghafalkan nama berbagai struktur anatomis, melainkan juga dituntut untuk mengerti hubungan spasial antar struktur secara tiga dimensi. Contohnya, untuk bidang neurologi, dibutuhkan pemahaman neuroanatomi yang komprehensif dan mendalam. ${ }^{2.5}$ Oleh sebab itu, pendidikan anatomi kedokteran selama beberapa ratus tahun terakhir bertumpu pada metode diseksi kadaver (pembedahan tubuh jenazah yang diawetkan) yang secara alami dapat menghadirkan hubungan tiga dimensi tersebut. ${ }^{4,5}$
Seiring dengan kemajuan zaman, kritik terhadap metode diseksi tradisional mulai bermunculan., 1,2,6 Diseksi kadaver kerap menghabiskan banyak waktu dan biaya. ${ }^{1-3}$ Selain itu, masalah etika menjadi penghalang dalam penggunaan kadaver. Padahal, kasus neurologi termasuk kasus yang sering ditemui dokter umum dan memerlukan pengetahuan neuroanatomi yang mumpuni untuk mendiagnosisnya. ${ }^{5}$ Di Indonesia sendiri, institusi pendidikan kedokteran mulai kesulitan untuk mendapatkan kadaver, karena pengadaan kadaver di Indonesia masih bersifat unclaimed body, belum dari donor tubuh (silent mentor) seperti yang sudah berjalan di beberapa negara saat ini. Hal tersebut menyebabkan kebutuhan media pembelajaran lain sebagai pengganti atau pelengkap pembelajaran anatomi dengan modalitas kadaver.?

Beberapa metode pembelajaran anatomi selain diseksi kadaver, yakni aplikasi anatomi tiga dimensi (3D) 
berbasis komputer termasuk penggunaan gawai meja visualisasi anatomi mulai direkomendasikan., ${ }^{1,2}$ Meja visualisasi anatomi dinilai mampu menghadirkan hubungan spasial lebih baik dibandingkan metode lain di luar diseksi atau proseksi kadaver, misalnya buku teks atau aplikasi anatomi dua dimensi (2D) berbasis komputer. ${ }^{1,89}$ Biaya yang lebih terjangkau dan tidak adanya masalah etika juga membuat meja visualisasi anatomi kerap direkomendasikan. Namun demikian, beberapa penelitian menunjukkan bahwa metode ini tidak dapat menggantikan penggunaan kadaver dan diperkirakan akan lebih efektif apabila dipasangkan bersamaan dengan diseksi kadaver atau sebagai pelengkap pembelajaran dengan modalitas kadaver. ${ }^{1,3,4,9,10}$ Pembelajaran visualisasi anatomi (anatomy visual learning, AVL) pada penelitian ini menggunakan meja visualisasi 3D dengan kemampuan manipulasi pada struktur yang identifikasi. Struktur dapat diperbesar hingga memperlihatkan struktur yang dalam, detil dan dapat dirotasi. ${ }^{4}$

Penelitian ini bertujuan untuk mengetahui apakah sejalan dengan pembelajaran menggunakan kadaver, pembelajaran visualisasi anatomi (anatomy visual learning, AVL) dengan meja visualisasi anatomi 3D dapat meningkatkan pengetahuan neuroanatomi mahasiswa dibandingkan dengan pembelajaran tanpa AVL. Penelitian ini juga bertujuan untuk mengetahui apakah mahasiswa memiliki persepsi positif mahasiswa terhadap pemanfaatan perangkat AVL dalam pembelajaran neuroanatomi. Hasil penelitian ini diharapkan mampu menambah informasi mengenai manfaat perangkat AVL dalam pembelajaran anatomi, khususnya neuroanatomi bagi mahasiswa program studi ilmu kedokteran.

\section{METODE}

Penelitian ini terdiri dari dua jenis studi, yaitu studi kuantitatif untuk mengetahui apakah penggunaan AVL dapat meningkatkan pengetahuan neuroanatomi mahasiswa Program Studi Pendidikan Dokter dan studi kualitatif untuk mengetahui persepsi mahasiswa Program Studi Pendidikan Dokter terhadap perangkat AVL. Studi kuantitatif dilaksanakan dengan desain studi uji pre-post multipel (multiple pre-post study). Kuesioner berisi sembilan butir pertanyaan dengan skala Likert dilakukan untuk mengetahui persepsi mahasiswa terhadap penggunaan AVL, sedangkan studi kualitatif dilakukan dengan pertanyaan terbuka saran penggunaan AVL.

Subyek penelitian adalah mahasiswa Program Studi Pendidikan Dokter Fakultas Kedokteran Universitas Indonesia (FKUI) tahun pertama (angkatan tahun 2017) dan belum pernah mengikuti pembelajaran neuroanatomi. Mahasiswa yang pernah mendapatkan materi neuroanatomi di FKUI di tempat atau institusi lain tidak diikutkan dalam penelitian, termasuk mahasiswa yang tidak mengikuti semua tahapan penelitian secara lengkap. Jumlah sampel dihitung berdasarkan penelitian yang dilakukan oleh Rae dkk. ${ }^{5}$ Hasil perhitungan didapatkan 22 subyek dan untuk menghindari kemungkinan drop out maka penghitungan jumlah subyek ditambahkan $10 \%$ menjadi total 50 subyek sehingga sebanyak 50 mahasiswa diambil secara acak dari mahasiswa angkatan 2017.

Satu minggu sebelum memasuki Modul Neurosains tahun ajaran 2018, semua subyek diwajibkan mengikuti pre-test. Pada tahap ini, 3 orang subyek dikeluarkan dari penelitian karena tidak mengerjakan pre-test sehingga total jumlah sampel menjadi 47 subyek. Setelah pre-test subyek dikelompokkan menjadi menjadi dua kelompok penelitian, yaitu kelompok kontrol $(\mathrm{N}=23)$ dan kelompok intervensi (perlakuan), $\mathrm{N}=24$ dengan teknik probability sampling yaitu simple random sampling.

Setelah pre-test, kedua kelompok akan mendapatkan sesi praktikum dengan kadaver sebanyak empat kali (2 jam/sesi) di laboratorium Anatomi Rumpun Ilmu Kesehatan Universitas Indonesia serta sesi pembelajaran berupa kuliah, diskusi kelompok, pleno dan praktikum neuroanatomi sesuai dengan jadwal Modul Neurosains. ${ }^{12}$

Subyek pada kelompok intervensi akan mendapatkan tambahan dua kali praktikum (2 jam/ sesi) menggunakan meja visualisasi anatomi 3D $(\text { SECTRATM })^{13}$ di Indonesia Museum of Health and Medicine (iMuseum) IMERI-FKUI. Sebelumnya, kepada subyek kelompok intervensi diberikan 
pelatihan cara pengoperasian meja visualisasi anatomi 3D. Setelah rangkaian proses pembelajaran selesai, seluruh subyek kembali diwajibkan untuk mengikuti post-test satu minggu sebelum ujian akhir. Pada tahap ini, satu orang subyek pada kelompok intervensi tidak mengerjakan post-test sehingga dikeluarkan dari penelitian. Dengan demikian, total sampel yang dianalisis adalah 46 subyek, masingmasing kelompok kontrol dan intervensi $(\mathrm{N}=23)$.

Pre-test dan post-test menggunakan instrumen berupa pertanyaan berjumlah 25 pertanyaan yang mencakup neuroanatomi dasar dan aplikasi klinisnya. Pertanyaan dijawab dengan isian singkat. Total skor didapatkan dari total jawaban benar dikalikan empat (skor 0-100).

Setelah sesi post-test, subjek kelompok intervensi mengisi kuesioner mengenai persepsi pembelajaran neuroanatomi dengan penambahan perangkat AVL. Kuesioner berisi sembilan butir pertanyaan mengenai persepsi subyek penelitian terhadap penggunaan AVL yang merupakan modifikasi dari kuesioner Hu dkk, ${ }^{11}$ dengan model skala Likert yang telah divalidasi. Pertanyaan mencakup: (1) Penggunaan AVL membantu saya memahami neuroanatomi; (2) Menurut pendapat saya, struktur anatomi yang disajikan pada AVL jelas; (3) Saya berpikir dapat menggunakan AVL secara mudah; (4) Saya menikmati sesi pembelajaran neuroanatomi menggunakan AVL; (5) Saya menginginkan sesi AVL ditambahkan pada pembelajaran anatomi pada modul lainnya; (6) Sangat mudah bagi saya memahami neuroanatomi jika strukturnya divisualisasikan dalam AVL; (7) Saya memilih belajar anatomi menggunakan media visualisasi (PC/laptop/tablet) dibandingkan buku; (8) Saya nyaman menggunakan AVL; (9) Saya membutuhkan kunjungan museum anatomi untuk menambah pengetahuan neuroanatomi.

Setelah mengisi kuesioner, kelompok intervensi diberikan pertanyaan terbuka yaitu saran terkait penggunaan AVL sebagai data kualitatif.

Data kuantitatif berupa nilai pre-test dan posttest diolah dengan bantuan piranti lunak SPSS for Windows versi 20 melalui tahap editing, coding, cleaning, dan entry. Data studi kuantitatif dianalisis menggunakan statistik inferensial dengan analisis bivariat (crosstab) antara variabel bebas dengan variabel terikat untuk mencari p untuk menguji kemaknaan. Uji kemaknaan dilakukan dengan uji t-berpasangan. Dari proses tersebut akan diperoleh nilai $p$ yang akan dibandingkan dengan $\alpha$ yang telah ditetapkan $(0,05)$ dan interval kepercayaan (IK95\%). Jika nilai $p<0,05$, maka variabel bebas memiliki hubungan dikatakan bermakna.

Semua mahasiswa yang berpatisipasi pada penelitian ini telah menyatakan kesediaannya dan mengisi informed consent. Penelitian ini tidak dilakukan kaji etik karena merupakan bagian dari evaluasi pembelajaran.

\section{HASIL DAN PEMBAHASAN}

Pembelajaran neuroanatomi sangat menantang bagi mahasiswa dikarenakan kompleksnya struktur sistem saraf pusat. Memahami struktur saraf pusat terutama otak memerlukan kemampuan spasial yang cukup. ${ }^{14}$ Terlebih lagi, pada pembelajaran neuroanatomi dengan kadaver jumlah spesimen yang terbatas dan beberapa struktur yang diidentifikasi cukup kecil menjadi keterbatasan pembelajaran dengan kadaver. ${ }^{15}$ Kesulitan mempelajari neuroanatomi juga seringkali dirasakan oleh mahasiswa tahun pertama di Fakultas Kedokteran Universitas Indonesia.

Pembelajaran neuroanatomi dengan menggunakan meja visualisasi anatomi 3D, atlas 3D, aplikasi Augmented dan Virtual Reality dianggap mampu meningkatkan pemahaman neuroanatomi mahasiswa. ${ }^{3,4,6,15-17}$

Pada awalnya, studi ini melibatkan total 50 subyek, namun 3 orang dikeluarkan dari penelitian karena tidak mengerjakan pre-test sehingga jumlah sampel menjadi 47 subyek, kelompok kontrol $\mathrm{N}=23$ dan kelompok intervensi $\mathrm{N}=24$. Diakhir sesi, 1 orang tidak mengerjakan post-test sehingga dikeluarkan dari data. Total jumlah sampel yang dianalisis 46 orang dengan kelompok kontrol dan intervensi masingmasing $\mathrm{N}=23$.

Subyek terdiri dari mahasiswa kedokteran laki-laki dan perempuan dengan median usia 19 tahun (Tabel 
1). Skor pre-test menunjukkan bahwa kelompok intervensi memiliki nilai median yang lebih tinggi daripada kelompok kontrol yaitu $8(0-30)$ vs. 3 (042), namun perbedaan ini secara statistik tidak bermakna $(p=0,869)$. Hal ini dapat mengerti karena kedua kelompok belum pernah mendapatkan materi neuroanatomi.

Tabel 1. Demografi subyek penelitian, skor pre-test, post-test dan peningkatan skor post-test dari skor pre-test kedua kelompok penelitian

\begin{tabular}{|c|c|c|c|}
\hline & $\begin{array}{l}\text { Kelompok intervensi } \\
\qquad(\mathbf{n}=23)\end{array}$ & $\begin{array}{l}\text { Kelompok kontrol } \\
\qquad(\mathrm{n}=23)\end{array}$ & p-value \\
\hline Usia [median (min-max)] & $19(18-20)$ & $19(17-20)$ & \\
\hline \multicolumn{4}{|l|}{ Jenis Kelamin } \\
\hline Laki-laki [n (\%)] & $14(60,9 \%)$ & $11(47,8 \%)$ & \\
\hline Perempuan [n (\%)] & $9(39,1 \%)$ & $12(52,2 \%)$ & \\
\hline Skor Pre-test [median (min-max)] & $8(0-30)$ & $3(0-42)$ & 0,869 \\
\hline Skor Post-test [median (min-max)] & $44(30-82)$ & $40(8-84)$ & 0,068 \\
\hline Peningkatan skor $[$ mean $\pm \mathrm{SD}]$ & $41,6 \pm 18,06$ & $29,8 \pm 20,47$ & 0,045 \\
\hline
\end{tabular}

Hasil post-test kelompok intervensi mempunyai median skor post-test lebih tinggi dibandingkan kelompok kontrol, yaitu 44 (30-82) vs. 40 (8-84), tetapi skor ini tidak bermakna secara statistik $(p=0,068)$. Hasil ini mungkin disebabkan tingkat kesulitan dan kedalaman pertanyaan pada post-test yang melibatkan struktur 3D. Juga tidak dilakukan analisis soal yang kompleks dan mudah. Sejalan dengan hasil ini, studi lain juga menunjukkan tidak ada perbedaan bermakna antara kelompok kontrol dan perlakuan ${ }^{6,18,19}$ namun pada analisis lebih lanjut perbedaan bermakna ditemukan pada soal dengan struktur yang kompleks yang melibatkan struktur internal otak. ${ }^{18}$

Meskipun tidak ada perbedaan bermakna pada nilai median pre-test dan post-test antara kedua kelompok, rerata (mean) peningkatan skor post-test dari skor pre-test pada kelompok intervensi $(41,6 \pm 18,06)$ ternyata berbeda secara bermakna ( $p<0,05$; IK95\%) dibandingkan dengan kelompok kontrol (29,8 \pm 20,47) (Tabel 1). Juga, jika dianalisa berdasarkan standar nilai kelulusan ujian di FKUI, yaitu $x=55$, mahasiswa dalam kelompok intervensi yang lulus post-test lebih banyak dibandingkan dengan kelompok kontrol (9 vs 6; data tidak ditampilkan). Hasil ini menunjukkan bahwa intervensi berupa penambahan perangkat meja visualisasi anatomi 3D dalam pembelajaran neuroanatomi dapat meningkatkan pengetahuan neuroanatomi mahasiswa secara bermakna.

Temuan ini sejalan dengan hasil kuesioner persepsi mahasiswa tentang penggunaan AVL dalam pembelajaran anatomi pada kelompok intervensi (Tabel 2). Sebagian besar (84,5\%) mahasiswa kelompok intervensi menunjukkan persepsi positif, yaitu setuju (50,2\%) dan sangat setuju (34,3\%); hanya $15,5 \%$ mahasiswa yang menunjukkan persepsi negatif, yaitu tidak setuju (12,6\%) dan sangat tidak setuju (2,9\%) terhadap pembelajaran visualisasi anatomi untuk menunjang pemahaman anatomi topik neuroanatomi. 
Tabel 2. Persepsi mahasiswa kedokteran tentang penggunaan AVL dalam pembelajaran neuroanatomi pada kelompok intervensi $(\mathrm{N}=23)$

\begin{tabular}{|c|c|c|c|c|c|}
\hline Pertanyaan & $\begin{array}{l}\text { Sangat } \\
\text { tidak setuju }\end{array}$ & $\begin{array}{l}\text { Tidak } \\
\text { setuju }\end{array}$ & Setuju & $\begin{array}{l}\text { Sangat } \\
\text { setuju }\end{array}$ & $\begin{array}{c}\text { Total } \\
\text { Setuju dan } \\
\text { Sangat setuju }\end{array}$ \\
\hline $\begin{array}{l}\text { Pertanyaan1: Penggunaan AVL membantu saya } \\
\text { memahami neuroanatomi }\end{array}$ & $4,4 \%$ & $0,0 \%$ & $60,9 \%$ & $34,8 \%$ & $95,7 \%$ \\
\hline $\begin{array}{l}\text { Pertanyaan 2: Menurut pendapat saya, struktur } \\
\text { anatomi yang disajikan pada AVL jelas }\end{array}$ & $4,4 \%$ & $4,4 \%$ & $60,9 \%$ & $30,4 \%$ & $91,3 \%$ \\
\hline $\begin{array}{l}\text { Pertanyaan 3: Saya berpikir dapat menggunakan } \\
\text { AVL secara mudah }\end{array}$ & $0,0 \%$ & $34,8 \%$ & $47,8 \%$ & $17,4 \%$ & $65,2 \%$ \\
\hline $\begin{array}{l}\text { Pertanyaan 4: Saya menikmati sesi pembelajaran } \\
\text { neuroanatomi menggunakan AVL }\end{array}$ & $4,4 \%$ & $0,0 \%$ & $60,9 \%$ & $34,8 \%$ & $95,7 \%$ \\
\hline $\begin{array}{l}\text { Pertanyaan 5: Saya menginginkan sesi AVL } \\
\text { ditambahkan pada pembelajaran anatomi pada } \\
\text { modul lainnya. }\end{array}$ & $0,0 \%$ & $8,7 \%$ & $43,5 \%$ & $47,8 \%$ & $91,3 \%$ \\
\hline $\begin{array}{l}\text { Pertanyaan 6: Sangat mudah bagi saya } \\
\text { memahami neuroanatomi jika strukturnya } \\
\text { divisualisasikan dalam AVL }\end{array}$ & $0,0 \%$ & $30,4 \%$ & $39,1 \%$ & $30,4 \%$ & $69,5 \%$ \\
\hline $\begin{array}{l}\text { Pertanyaan 7: Saya memilih belajar anatomi } \\
\text { menggunakan media visualisasi (PC/laptop/ } \\
\text { tablet) dibandingkan buku. }\end{array}$ & $8,7 \%$ & $13,0 \%$ & $39,1 \%$ & $39,1 \%$ & $78,2 \%$ \\
\hline Pertanyaan 8: Saya nyaman menggunakan AVL & $4,4 \%$ & $8,7 \%$ & $56,5 \%$ & $30,4 \%$ & $86,9 \%$ \\
\hline $\begin{array}{l}\text { Pertanyaan 9: Saya membutuhkan kunjungan } \\
\text { museum anatomi untuk menambah pengetahuan } \\
\text { neuroanatomi }\end{array}$ & $0,0 \%$ & $13,0 \%$ & $43,5 \%$ & $43,5 \%$ & $87,0 \%$ \\
\hline Rerata & $2,9 \%$ & $12,6 \%$ & $50,2 \%$ & $34,3 \%$ & $84,5 \%$ \\
\hline $\mathrm{SD}$ & $3,1 \%$ & $12,4 \%$ & $9,5 \%$ & $8,8 \%$ & $11,1 \%$ \\
\hline
\end{tabular}

Keterangan: nilai total dapat melebihi 100\% karena pembulatan

Sebanyak $95,7 \%$ mahasiswa setuju bahwa penggunaan AVL dapat membantu mahasiswa memahami neuroanatomi (pertanyaan 1) dan menikmati pembelajaran neuroanatomi menggunakan AVL (pertanyaan 4). Temuan ini sejalan dengan studi lain bahwa memahami struktur neuroanatomi agak berbeda dibandingkan dengan memahami struktur tubuh lainnya. Kompleksnya struktur anatomi otak memerlukan kemampuan visual-spasial yang lebih dibandingkan mempelajari organ lain. ${ }^{14,16}$

AVL memiliki beberapa keunggulan dibandingkan dengan aplikasi anatomi 3D lainnya. AVL memberikan kesempatan kepada mahasiswa untuk melakukan berbagai manipulasi, misalnya mengeksplorasi struktur anatomi dari berbagai sudut pandang, memperbesar, dan melabel struktur yang diinginkan. ${ }^{15}$ Pada penelitian ini, struktur neuroanatomi pada AVL berasal dari gambaran CT Scan atau MRI yang diubah dalam bentuk 3D. Hal ini menjadi keunggulan aplikasi AVL pada studi ini. Dengan demikian, mahasiswa dapat mempelajari hingga struktur detil neuroanatomi yang seringkali sulit diidentifikasi pada pembelajaran dengan kadaver didukung dengan persepsi positif $(91,3 \%)$ bahwa struktur anatomi yang disajikan pada AVL jelas (pertanyaan 2).

Menariknya, temuan ini juga sejalan dengan hasil systematic review Losco $\mathrm{dkk}^{1}$ yang mendapati bahwa 
pembelajaran anatomi dengan modalitas computer assisted learning dan anatomi 3D memberikan hasil dan kepuasan belajar yang lebih tinggi dibanding dengan metode belajar konvensional. Selain itu, penggunaan penunjang pembelajaran visualisasi anatomi dapat meningkatkan kemampuan spasial mahasiswa dalam memahami struktur neuroanatomi secara $3 \mathrm{D}^{2,14,16}$ yang pada akhirnya meningkatkan perolehan nilai post-test pada kelompok intervensi.

Keunggulan AVL ini sejalan dengan temuan hasil kuesioner lainnya. AVL menambah minat dan antusiasme mahasiswa dan dirasakan dapat melengkapi informasi yang dibutuhkan dalam pembelajaran anatomi, terbukti dengan tingginya rekomendasi agar sesi AVL ditambahkan pada pembelajaran anatomi modul yang lain (pertanyaan 5) yaitu 91,3\%. Selain itu, mahasiswa juga merasa nyaman dalam menggunakan AVL (pertanyaan 8) disampaikan oleh 86,9\% mahasiswa. Kembali kepada keunggulan AVL, kemudahan memanipulasi struktur memberikan persepsi positif pada pembelajaran dengan AVL.

Sebanyak 78,2\% mahasiswa memilih belajar anatomi dengan metode visualisasi dibandingkan dengan buku (pertanyaan 8). Namun demikian masih terdapat $21,7 \%$ yang tidak setuju sehingga dapat disimpulkan mahasiswa masih memerlukan bantuan buku untuk pembelajarannya. Hal ini sejalan dengan penelitian Park S dkk ${ }^{17}$ yang mengindikasikan bahwa mahasiswa menyukai penggunaan atlas 3D apabila diintegrasikan dengan atlas 2D.

Temuan yang menarik dari hasil kuesioner ini juga didapati $34,8 \%$ mahasiswa tidak setuju jika mereka dapat mengoperasikan modalitas AVL dengan mudah (pertanyaan 3). Hal ini sejalan dengan ketidaksetujuan 30,4\% mahasiswa bahwa akan sangat mudah memahami neuroanatomi jika strukturnya divisualisasikan dalam AVL (pertanyaan 6). Hal ini bisa dipahami karena dalam pemanfaatan AVL diperlukan adaptasi teknologi dan pelatihan teknis pengoperasian perangkat terlebih dahulu. Hasil ini juga mendukung pendapat bahwa pembelajaran anatomi dengan AVL harus sejalan dengan pembelajaran konvensional, yaitu menggunakan kadaver. Kedua modalitas ini akan saling melengkapi kekurangan masing-masing dalam menunjang pembelajaran anatomi. ${ }^{6-10}$ Selain itu, kemampuan visual-spasial mempunyai andil dalam pembelajaran AVL.

Mahasiswa juga membutuhkan kunjungan museum anatomi untuk menambah pengetahuan neuroanatomi (87\%). AVL pada penelitian terletak di iMuseum IMERI FKUI. Hal ini juga menjadi keuntungan untuk mahasiswa karena selain AVL pada museum juga terdapat spesimen neuroanatomi lainnya.

Pada kelompok intervensi diberikan pertanyaan terbuka terkait saran terkait penggunaan AVL (Tabel 3). Saran pengunaan AVL dapat dibagi menjadi dua kategori, yaitu terkait metode pembelajaran dan penggunaan AVL. Temuan yang menarik terkait metode pembelajaran mahasiswa adalah keinginan AVL dijadikan pembelajaran wajib dalam modulmodul lainnya selain neuroanatomi, Hal ini sesuai dengan hasil kuesioner pada pertanyaan 3 (91,3\% mahasiswa menginginkan AVL ditambahkan pada pembelajaran anatomi modul lainnya).

Tabel 3. Saran penggunaan AVL pada kelompok intervensi

Kategori

Penggunaan AVL
Respon

Diadakan untuk semua mahasiswa secara bergiliran

Dibagi kelompok2 kecil (5 orang) dan dibiarkan eksplorasi secara mandiri dengan AVL dan diberi waktu yang cukup (3 jam)

Jadikan wajib dalam modul agar semua lebih jelas memvisualisasikan anatomi Sudah cukup baik, terutama saat penjelasan dengan orang terbatas

Sudah sangat baik namun akan lebih baik lagi jika diinformasikan terlebih dahulu materi apa yang akan dipelajari menggunakan AVL

AVL kadang terlalu lambat

Masih terdapat lagging dan kualitas gambar dibawah ekspektasi 
Mahasiswa juga menyarankan pembelajaran dengan AVL dilakukan dengan kelompok kecil mahasiswa dan bergiliran setiap mahasiswa. Pembelajaran dengan AVL juga dianggap cukup baik terutama dengan jumlah peserta yang terbatas. Dengan jumlah peserta dan terbatas atau dibagi dalam kelompok kecil (5 orang), mahasiswa dapat lebih leluasa mempelajari AVL. Meja visualisasi anatomi yang digunakan pada penelitian ini adalah SECTRA table yang memiliki lebar layar sekitar $165 \mathrm{~cm}^{13}$ dengan demikian dapat dipahami mahasiswa menginginkan pembelajaran dalam kelompok kecil. Belum ada penelitian terkait jumlah mahasiswa yang optimal untuk mengakses AVL sehingga saran tersebut dapat menjadi temuan baru dalam penelitian ini. Namun demikian masih terdapat kendala dalam penggunaan AVL, gambar yang ditampilkan pada layar kadang terdapat lagging atau dianggap terlalu lambat. Hal ini mungkin terjadi pada saat awal mengaktifkan AVL.

Penelitian ini memiliki beberapa keterbatasan antara lain, tidak dianalisis tingkat kesulitan soal pre-post dan post-test yang mungkin mempengaruhi hasil penelitian. Selain itu, kemampuan spasial peserta juga tidak diukur. AVL merupakan meja dengan teknologi terkini yang memerlukan pelatihan khusus dalam pengoperasiannya.

\section{KESIMPULAN}

Penggunaan pembelajaran visualisasi anatomi dapat meningkatkan pengetahuan neuroanatomi kelompok intervensi dibandingkan dengan kelompok kontrol dan memberikan persepsi positif bagi penggunanya yang dibuktikan dengan peningkatan skor post-test dan persepsi positif penggunaan AVL. Pembelajaran dengan AVL akan lebih optimal dilakukan dalam kelompok kecil. Dengan demikian, perangkat pembelajaran visualisasi anatomi dapat direkomendasikan sebagai perangkat tambahan atau pelengkap pembelajaran neuroanatomi, sejalan dengan penggunaan kadaver.

\section{SARAN}

Penerapan pembelajaran AVL khususnya pada modul-modul anatomi dapat implementasikan bersamaan dengan pembelajaran dengan kadaver sebagai pendukung pembelajaran, namun dilakukan dalam kelompok kecil. Penting dilakukan pelatihan teknis pengoperasian meja visualisasi anatomi 3D secara khusus sehingga mahasiswa mendapatkan manfaat yang optimal. Selain itu, perlu dilakukan pengembangan suatu sistem yang memungkinkan mahasiswa mengakses AVL secara khusus, misalnya diperangkat komputernya masing-masing. Dengan demikian pembelajaran dengan AVL menjadi lebih efektif dan mudah bagi mahasiswa.

\section{DEKLARASI KEPENTINGAN}

Para penulis mendeklarasikan bahwa tidak terdapat konflik kepentingan apapun terkait studi pada naskah ini.

\section{KONTRIBUSI PENULIS}

Sasanthy Kusumaningtyas - mendesain penelitian, supervisi jalannya penelitian, interpretasi data, terlibat dalam penyusunan, revisi dan finalisasi manuskrip.

Mochamad Iskandarsyah Agung Ramadhan mendesain penelitian, pengambilan data dan analisis data, terlibat dalam penyusunan manuskrip.

Ria Margiana - supervisi jalannya penelitian, saran desain penelitian dan persetujuan manuskrip.

Elvan Wiyarta - terlibat dalam penyusunan tinjauan pustaka.

Reynardi Sutanto - terlibat dalam penyusunan tinjauan pustaka.

Isabella Kurnia Liem - memberikan ide penelitian, terlibat dalam penyusunan dan revisi manuskrip.

\section{DAFTAR PUSTAKA}

1. Losco CD, Grant WD, Armson A, Meyer AJ, Walker BF. Effective methods of teaching and learning in anatomy as a basic science: A BEME systematic review: BEME guide no. 44. Med Teach [Internet]. 2017; 39(3): 234-43. Available from: http://dx.doi. org/10.1080/0142159X.2016.1271944

2. Estai M, BuntS. Best teaching practices in anatomy education: a critical review. Ann Anat [Internet]. 2016; 208: 151-7. Available from: http://dx.doi. org/10.1016/j.aanat.2016.02.010 
3. Allen LK, Eagleson R, de Ribaupierre S. Evaluation of an online three-dimensional interactive resource for undergraduate neuroanatomy education. Anat Sci Educ. 2016; 9(5): 431-9.

4. Azer SA, Azer S. 3D anatomy models and impact on learning: a review of the quality of the literature. Heal Prof Educ [Internet]. 2016; 2(2): 80-98. Available from: http://linkinghub. elsevier.com/retrieve/pii/S2452301116300281

5. Rae G, Cork RJ, Karpinski AC, Swartz WJ. The integration of brain dissection within the medical neuroscience laboratory enhances learning. Anat Sci Educ. 2016; 9(6): 565-74.

6. Anand MK, Singel TC. A comparative study of learning with "anatomage" virtual dissection table versus traditional dissection method in neuroanatomy. Indian J Clin Anat Physiol. 2017; 4(2): $177-80$

7. Romi MM, Arfian N, Sari DCR. Is cadaver still needed in medical education? J Pendidikan Kedokteran Indonesia [internet]. 2019; 8(3): 105-12. Available from: https://jurnal.ugm.ac.id/jpki/ article/view/46690/26344

8. Van Nuland SE. Examination and assessment of commercial anatomical e-learning tools: software usability, dual-task paradigms and learning. University of Western Ontario. Electronic Thesis and Dissertation Repository. 4615 [internet] 2017. Available from: https://ir.lib.uwo.ca/etd/4615

9. Poulton R, Caspi A, Milne BJ, Thomson WM, Taylor A, Sears MR, et al. Learning with interactive computer graphics in the undergraduate neuroscience classroom. Adv Heal Sci Educ Theory Pr. 19(4): 507-28.

10. Memon I. Cadaver dissection is obsolete in medical training! A miss interpret notion. Med Print Pract. 2018; 27: 201-10

11. Hu A, Wilson T, Ladak H, Haase P, Fung K. Three-dimensional educational computer model of the larynx: voicing a new direction. Arch Otolaryngol Head Neck Surg. 2009 Jul; 135(7): 677-81. doi: 10.1001/archoto.2009.68.
12. Tim modul neurosains. Buku panduan kegiatan mahasiswa (BPKM) neurosains tahun ajar 2018. Salemba: Fakultas Kedokteran Universitas Indonesia; 2018: 47

13. Sectra. Sectra Terminals for medical education. Sectra Medical [webpage on internet]. No date [accessed on 2020 September 10]. Available from: https://medical.sectra.com/product/sectraterminals/.

14. Allen L, Eagelson R, deRibaupierre S. Effect of spatial ability on enhancing neuroanatomy education with an interactive 3D e-learning module. FASEB J. 2016; 30 (Suppl 1): 570-6

15. Javaid M, Schellekens H, Cryan J, Toulouse A. Neuroanatomy of the spinal pathways: Evaluation of an interactive multimedia e-learning resourse. MedEdPublish [internet]. 2020; 9(1): 88. Available from: https://doi.org/10.15694/ mep.2020.00088.1.

16. Arantes M, Arentes J, Ferreira MA. Tools and resources for neuroanatomy education: a systematic review. BMC Med Educ [internet]. 2018; 18: 94. Available from: https:// bmcmededuc.biomedcentral.com/track/ pdf/10.1186/s12909-018-1210-6.

17. Park S, Kim Y, Park S, Shin JA. The Impacts of three-dimentional anatomical atlas on learning anatomy. Anat Cell Biol. 2019; 52(1): 76-81.

18. Drapkin ZA, Lindgren KA, Lopez MJ, Stabio ME. Development and assessment of a new 3D neuroanatomy teaching tool for MRI training. Anat Sci Educ [internet]. $2015 \mathrm{Nov}-\mathrm{Dec} ; 8(6)$ : 502-9. Available from: http://doi: 10.1002/ ase. 1509 .

19. Donnelly L, Patten D, White P, Finn G. Virtual human dissector as a learning tool for studying cross-sectional anatomy. Med Teach. 2009; 31(6): 553-555, DOI: 10.1080/01421590802512953 